\author{
Czesław Machelski \\ Prof. dr hab. inż. \\ Politechnika Wrocławska \\ Wydział Budownictwa Lądowego i Wodnego \\ Katedra Dróg, Mostów, Kolei i Lotnisk \\ czeslaw.machelski@pwr.edu.pl
}

\author{
Jan Bernard Michalski \\ Dr inż. \\ EKSPERT sp. z o.o.. \\ benitamichalska@onet.pl
}

DOI: 10.35117/A_ENG_21_03_01

\title{
Scheme analysis of the structure founded on the piles in soil-steel bridge
}

\begin{abstract}
In soil-steel bridges usually the massive concrete foundation is being applied. When the structure is mounted in the gutter, the static models defined as non-sliding joint arch. In a few cases only, the corrugated steel structures are founded on a flexible foundation. The examples of such objects executed in Poland were described in this article. The flexible foundation of the steel structure helps to form a natural vault in the backfill. The shape of the structure, similar to parabolic arch, is relevant in this case. The essential case being analyzed here, is the structure founded on the piles made of steel pipes. It is characterized by variable static scheme resulting from the level of connection. The displacement scheme was established using the results of geodetic measurements performed on the constructed bridge. On this basis, the range of changes in the uplift of the structure during backfilling, was estimated in the structure model.
\end{abstract}

Keywords: Soil-steel bridges; Flexible foundation; Static scheme; Investigation

\section{Types of corrugated sheet shells foundations}

Direct foundation applies only to shells made of corrugated steel sheets with a closed crosssection (elliptical, droplet, pear-shaped). In such situations, a sand bed is used under the lower part of the shell. In the case of larger objects, an aggregate base is made, on which profiling of the proper contact layer of the backfill with the shell is carried out.

Direct foundation can also be used in the case of an active watercourse. In [1] the technology of building a culvert located along the Niemodlin - Lewin Brzeski road is discussed. The obstacle was a canal with a constant but high water level with a very low hydraulic drop. The $3 \mathrm{~m}$ wide culvert is made of a steel shell made of corrugated sheet MP $150 \times 50 \times 5 \mathrm{~mm}$. The pipe was twisted from sheets of metal near the place of its incorporation, and after assembling the entire steel structure, it was inserted into the channel, as in Fig. 1. In such a case of tubular shells, deformation of the geometry along its longitudinal axis is important. 


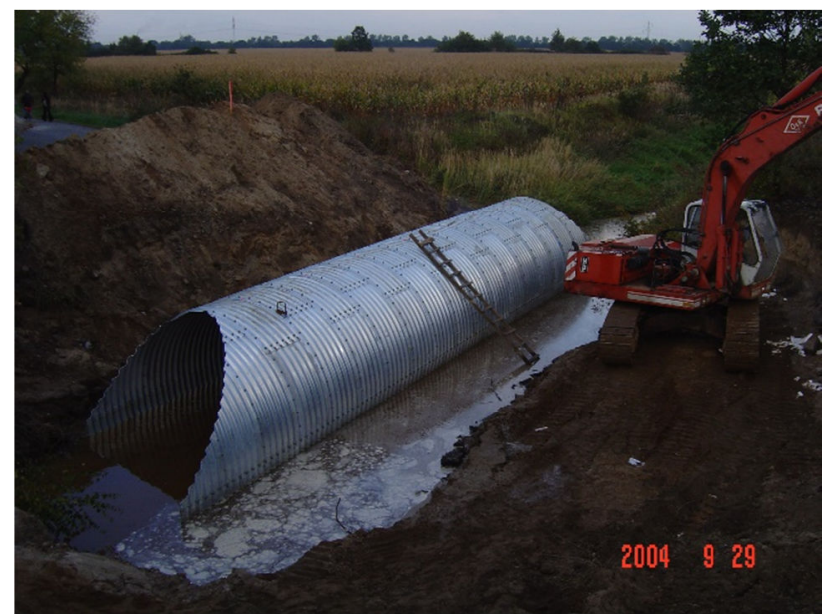

1. Construction of an object in a watercourse

In the case of shells with an open cross-section, the most common is found on a reinforced concrete foundation. Such foundations can also be realized with the use of prefabrication. Significant in the analyzed type of structure is embedding the shell in a gutter made of steel section and fixing it with screws. A nest formed in the upper part of the concrete support is also used. This group also includes supports on massive footings crowning reinforced concrete piles [2, 3], as shown in Fig. 2. The common feature of these structures is the connection of the shell with the foundation in a way that creates a support pattern as articulated and non-sliding.

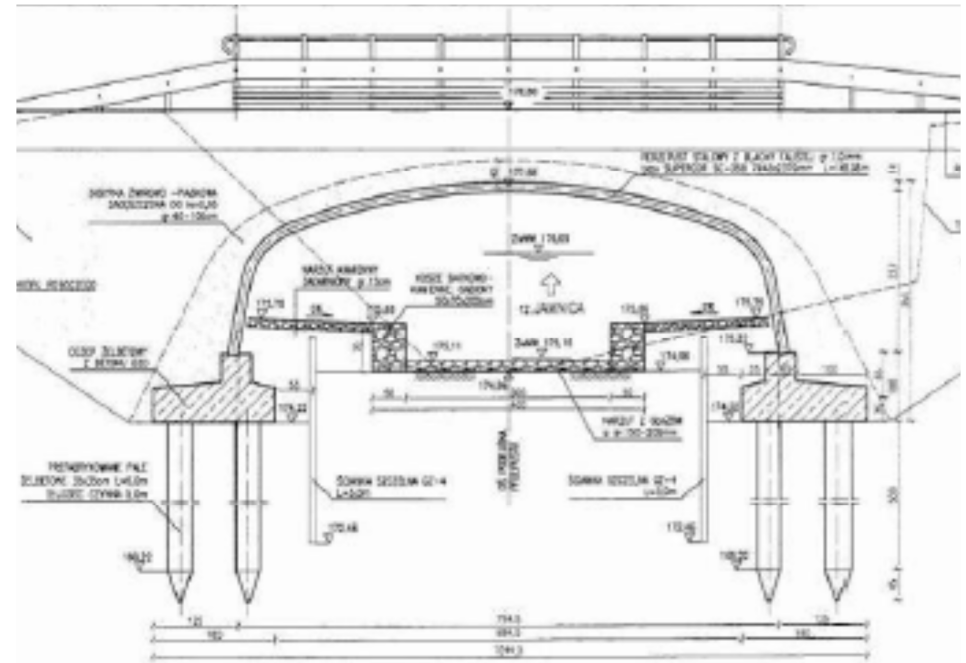

2. Supporting the shell on the foundation with the use of reinforced concrete piles

The classic, rigid foundation of the shell on massive foundations may be appropriate for longspan shells. For small objects, flexible supports as in the examples given below are sufficient. It results from low values of vertical support reactions with much greater side effects. In the building built in Biernacice [4], a thin wall was made with ribbing on the extension of reinforced concrete piles. The side walls are a vulnerable part of the structure of the facility. Thus, the structural system is mixed - the lower part is made of concrete and the upper part is made of a classic corrugated sheet shell. When the shell is supported in a gutter, it can be classified as a typical soil- shell object with a non-sliding hinge pattern.

Fig. 3 shows an example of the integrated connection of the shell with the foundation element in the form of a corrugated sheet [5]. 


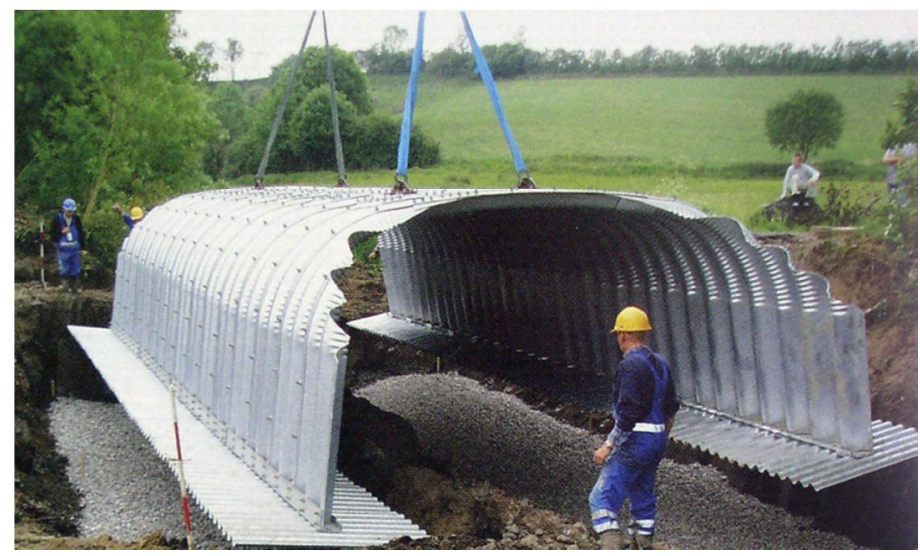

3. Structure of a shell with support on a corrugated sheet [5]

The entire, light steel structure is placed on a gravel bed. An example of the analyzed type of foundation was used in a facility built in Mikołajki [6].

The integrated support of the shell on the vertical wall of corrugated steel, as shown in Fig. 4, was designed in a facility located along a local road with little traffic, but for heavy vehicle weights, in Bartnica near Nowa Ruda [7].
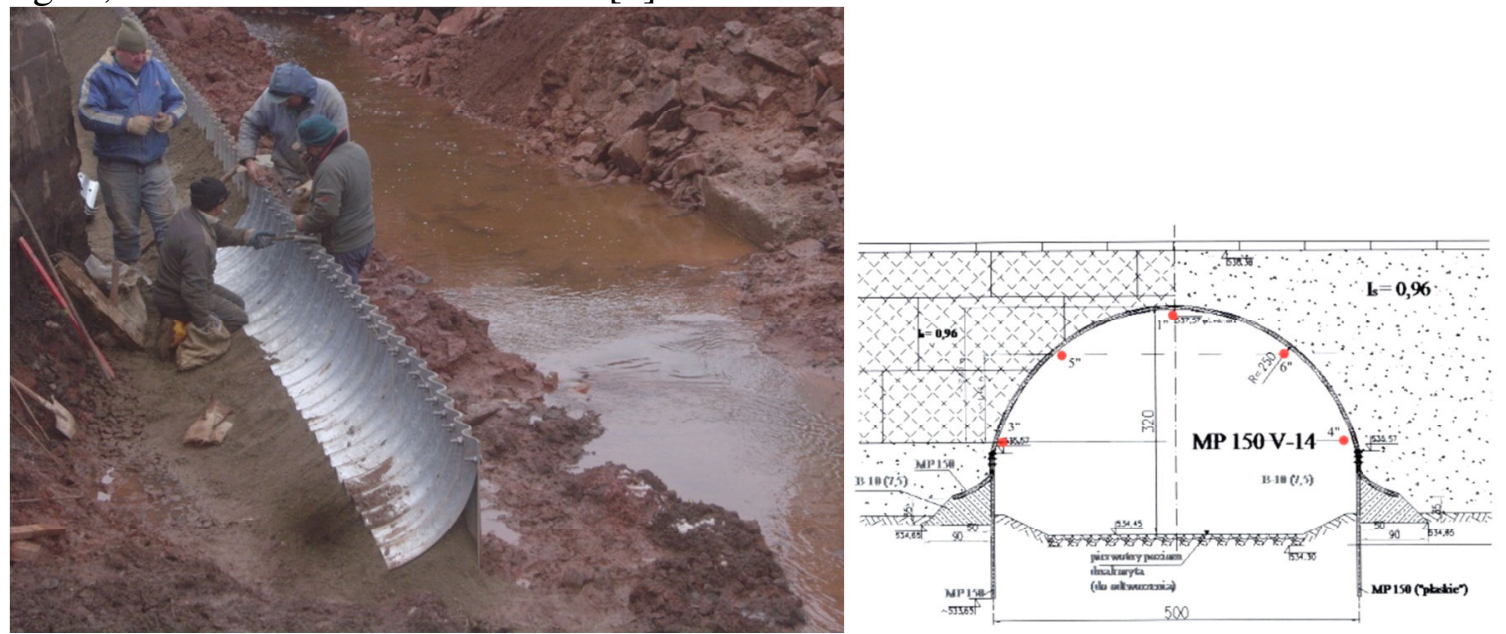

4. The coating placed on a wall made of corrugated steel, with a grouser

In the cross-section, the structure creates a scheme of a half-circle arch with a diameter of 5.0 $\mathrm{m}$. A shell made of MP $150 \times 50 \times 5$ sheet was designed. The shell is immersed in the native soil to a depth of approx. $1 \mathrm{~m}$. An important element of the support structure in this case is a spur made of corrugated steel. The spur is attached to the shell with bolts, such as those used for joining corrugated sheets. It is based on low-strength concrete - it is intended to prevent the coating from settling. Thus, such a system can be classified as a structure made of a sheet immersed in the soil medium.

Foundation on piles in soil and shell structures is rarely used. Point support for the shell was used in the temporary structure, as shown in Fig. 5. It was built on the national road No. 8, on the Wrocław - Kłodzko route near the town of Niemcza [8]. 


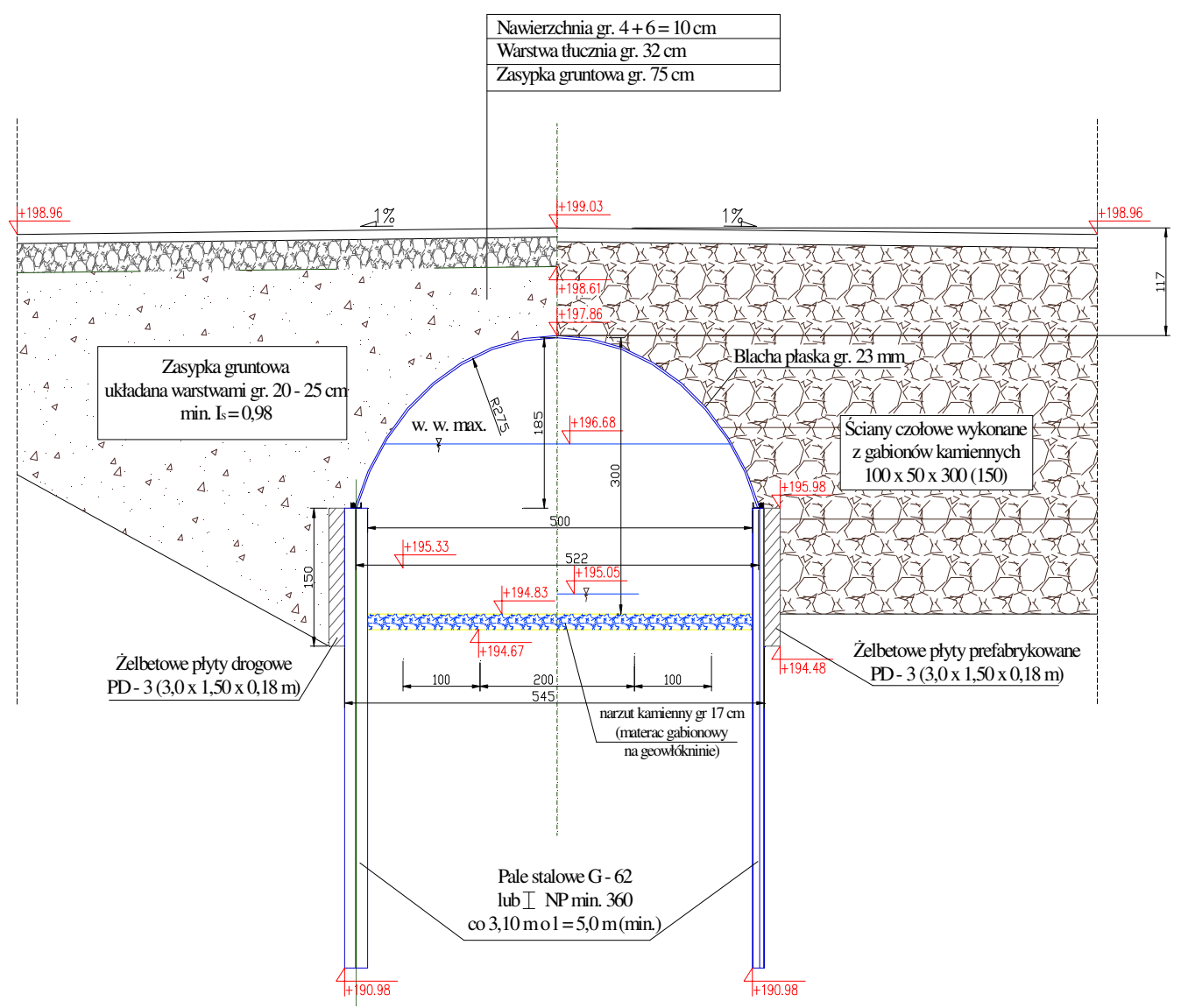

5. A flat sheet shell founded on the piles

In this case, the steel section gutter was the top of the piles driven into the native soil. The spacing of the piles made of steel sections was $3,1 \mathrm{~m}$. A special case is the use of a flat steel shell with a thickness of $t=23 \mathrm{~mm}$. In the cross-section, the shell is half-circle-shaped and has a span of $L=5,25 \mathrm{~m}$. In the static scheme of the articulated support, the possibility of horizontal displacements resulting from the compliance of the piles and the earth pressure effect as well as the expansion force coming from the shell.

\section{The integrated foundation of the shell with piles}

The structure analyzed in the study is the structure built in Świdnica [8] over the railway line, as shown in Fig. 6. The coating of the soil and shell structure is made of a corrugated steel sheet, type MP $200 \times 55 \times 5,5$. 


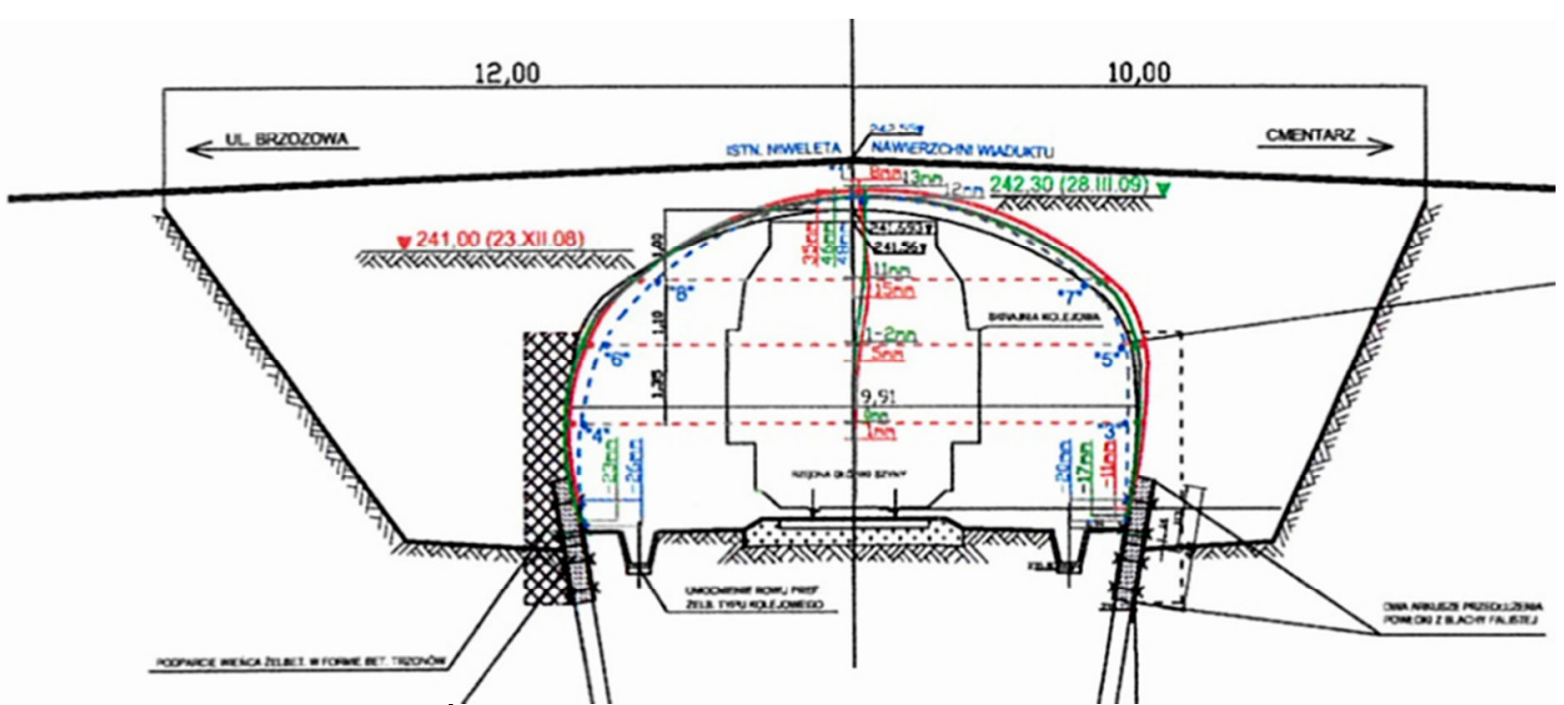

6. Object in Świdnica with a shell structure integrated with piles

The cross-section of the circumferential strip of the coating shows a complex shape in the form of a circular arc with a span of $L=10,05 \mathrm{~m}$ and a radius of curvature $R=8,984 \mathrm{~m}$ and in the corner $R_{\mathrm{n}}=1,335 \mathrm{~m}$. rigid with piles made of steel pipes $300 \times 5 \mathrm{~mm}$, spaced every $2.5 \mathrm{~m}$. In the transitional part of the structure, there is a double-sided coating covering the upper section of the pipe. This fragment between the corrugated sheets was a formwork to be filled with concrete. In this way, an integrated connection of the shell with the steel piles was created.

The static scheme of the shell in Świdnica is complex because the support on the piles is integrated with the shell. A significant problem considered in the paper is the determination of the level of the shell fastening in piles. Fig. 7 shows a diagram of the deformation of the circumferential strip of the shell during the laying of the soil backfill. In the analyzed structure, it is convenient to adopt a reference level (coordinate system) in the shell key. In this diagram, point 0 changes its position during construction and operation. 


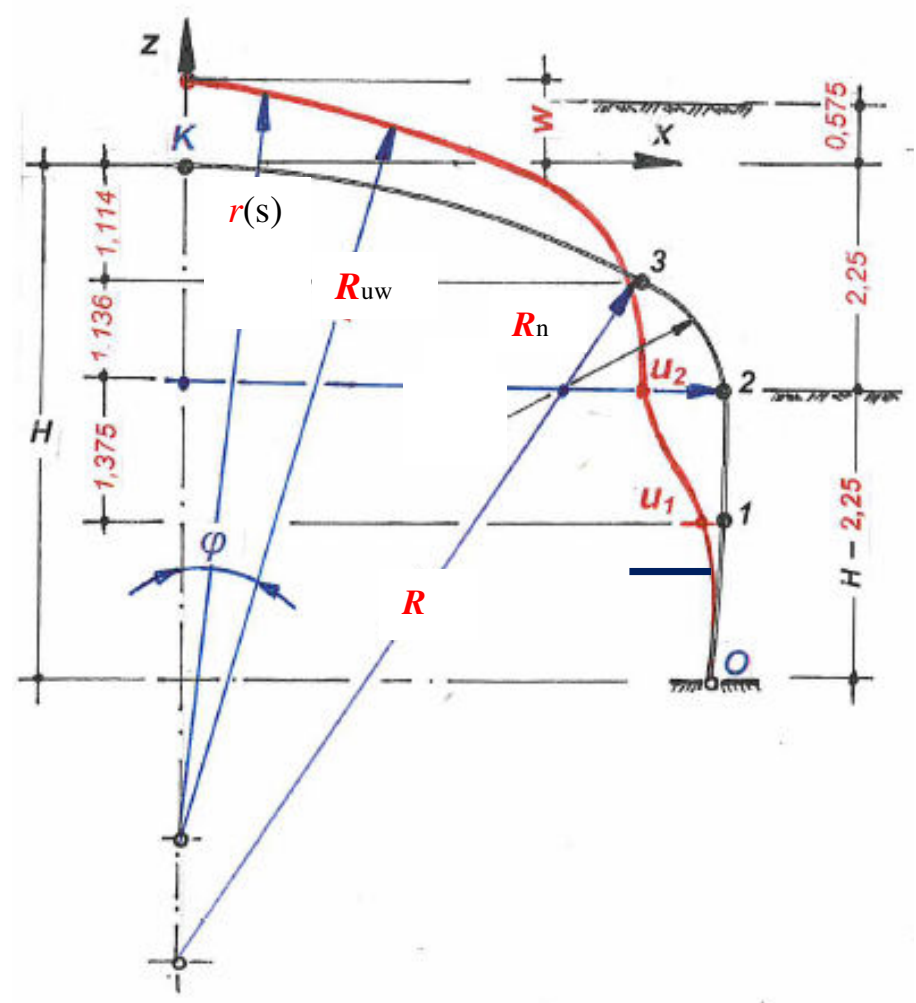

7. Geometry of the circumferential strip of the Świdnica shell

During construction, i.e. during the laying of the soil backfill, the greatest displacements of the coating occur as a result of the influence of the soil. To observe the changes in shell deformation, the study used geodetic techniques with a measuring base located on both sides of the shell. Based on these displacements, the graphs shown in Fig. 8 were created, where the variable parameter is the backfill level $\mathrm{z}$ as the vertical coordinate from the shell key. Thus, when $\mathrm{z}<0$ the backfill is placed below the shell key. During construction, the symmetry of the system is recommended, as shown in Fig. 7.

The uplift of the shell key at $w(\mathrm{~K})$ is positive (towards the outside, in line with the $z$-axis), while the constrictions $u$ are negative (towards the inside), as in Fig. 7. A characteristic feature of these results is the increase in horizontal displacements of points 1,2, 3 when the backfill is built above the coating $(\mathrm{z}>0)$. The important thing is that the coating does not experience any reduction of the taper during backfilling. Thus, there is an advantage of the pressure on the sidewalls over the expansion force of the arch, i.e. part of the top shell. The changes in the displacement $u_{3}$ are visible in these measurements when the backfill exceeds the level of measurement point 3. In the case of arc-shaped shells placed on a massive foundation, horizontal displacements are usually significantly reduced when the backfill level approaches the key (i.e. when $\mathrm{z} \approx 0$ ).

\section{Estimating the level of shell mounting}

The results of the measurements given in Fig. 8 were used to determine the displacement lines of the circumferential band of the coating given in Fig. 9. The displacements on these graphs are directed radially (perpendicularly) to the line of the circumferential band of the coating they are marked as $r$ in Fig. 7. 


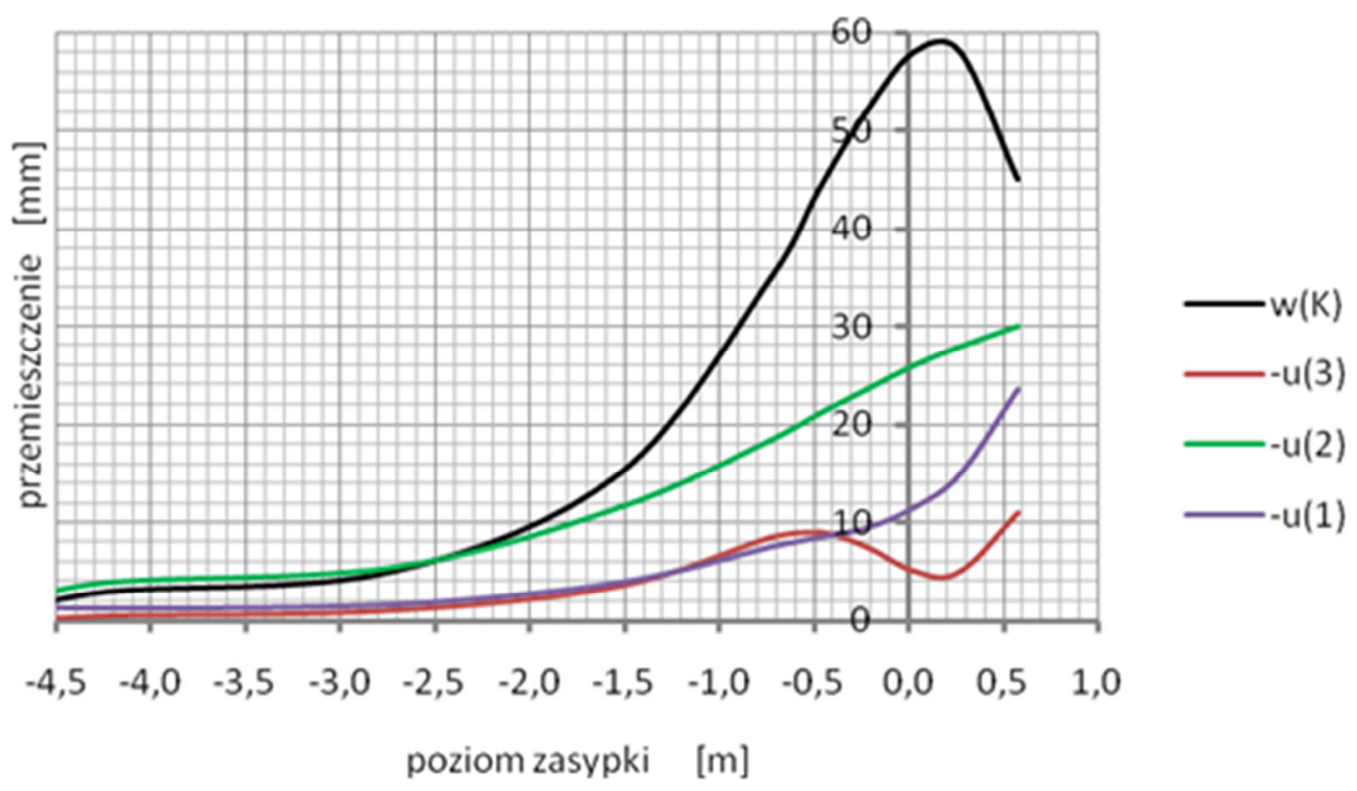

8. Changes in displacement of measuring points during the arrangement of the backfill

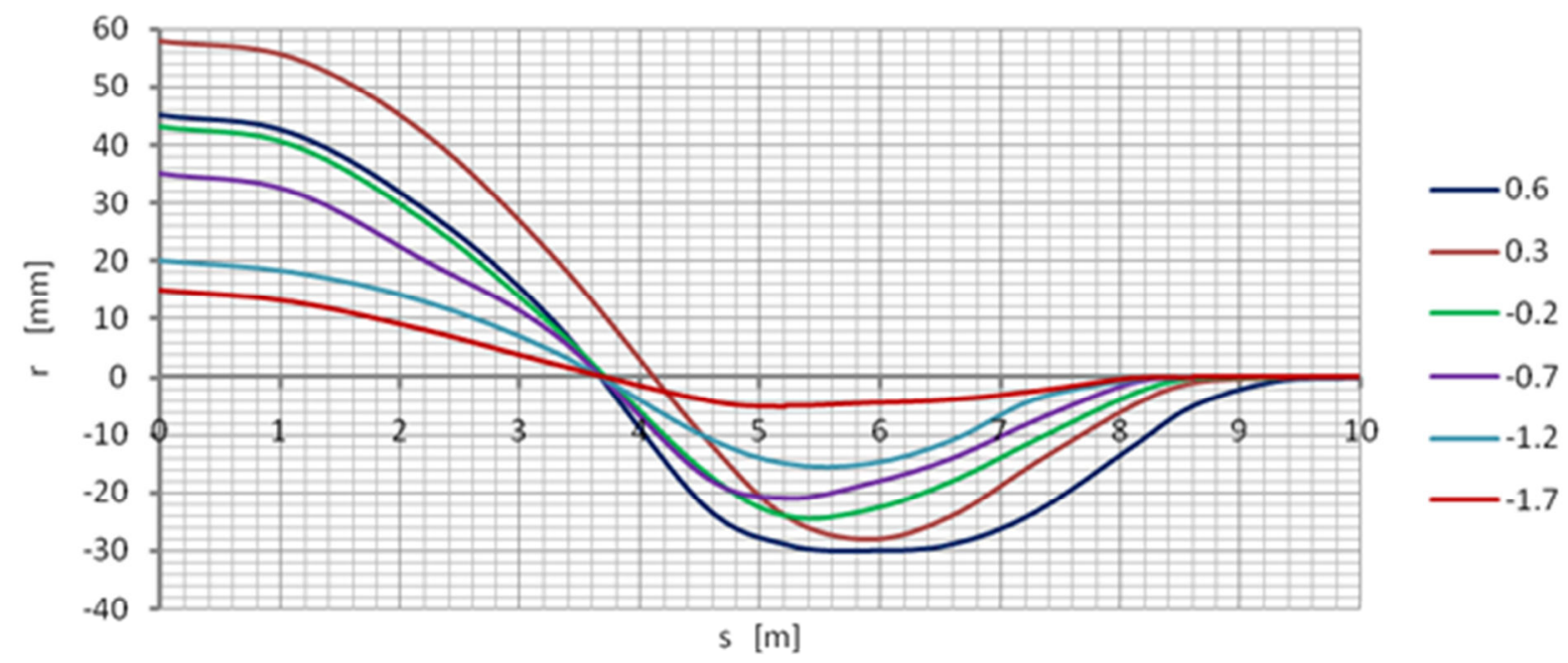

9. Lines of displacements in the radial direction of the circumferential strip of the shell

In this case, the location of the measurement points was defined as the distance from the key $s$ but calculated along the axis of the circumferential strip of the coating. In the case of a circular sector-shaped part, the value of $s$ is determined from the geometrical relation given in Fig. 7 as

$$
s=\varphi \cdot R \text {. }
$$

In formula (1) it was assumed that the change in the radius of curvature during construction is small, so there is a relation $R \approx R_{\text {uw }}$.

The locations of the measurement points on the circumferential band are as follows: $s_{\mathrm{K}}=0, s_{3}$ $=4,521 \mathrm{~m}, s_{2}=5,908 \mathrm{~m}$ and $s_{1}=7,283 \mathrm{~m}$. Based on the graphs in Fig. 9, the place where $r=$ 0 occurs was estimated as $s_{0}$. On this basis, the location of the shell is determined, i.e. the shell height $H$, taken in the static diagram, depends on the value $s_{0}$, as in the formula

$$
H=\left(s_{o}-s_{2}\right)+2,25
$$

In the chart legend, the level of backfill with reference to the shell key is given. 
All charts are arranged in a characteristic way. With the increase in the thickness of the backfill, point 0 in Fig. 7 is lowered. In the case of placing the soil over the curvilinear part of the coating, the $H$ value increases significantly. It results from the increase of the narrowing, which should be treated as the advantage of the pressure on the sidewalls over the expansion force of the arched part of the shell. The uplift increments are greater than that found in arched shells supported in a massive foundation. For small backfill thickness with the level reaching point $1, \mathrm{H}=4.5 \mathrm{~m}$ can be assumed $\left(\mathrm{s}_{\mathrm{o}}=8,2 \mathrm{~m}\right)$.

\section{Effectiveness of the soil - shell influence}

The change of the static pattern, i.e. the place where the shell is attached in the foundation, affects the effectiveness of the soil's impact on the shell p (s). It is captured by the line of influence of the lifting of the shell key shown in Fig. 10.

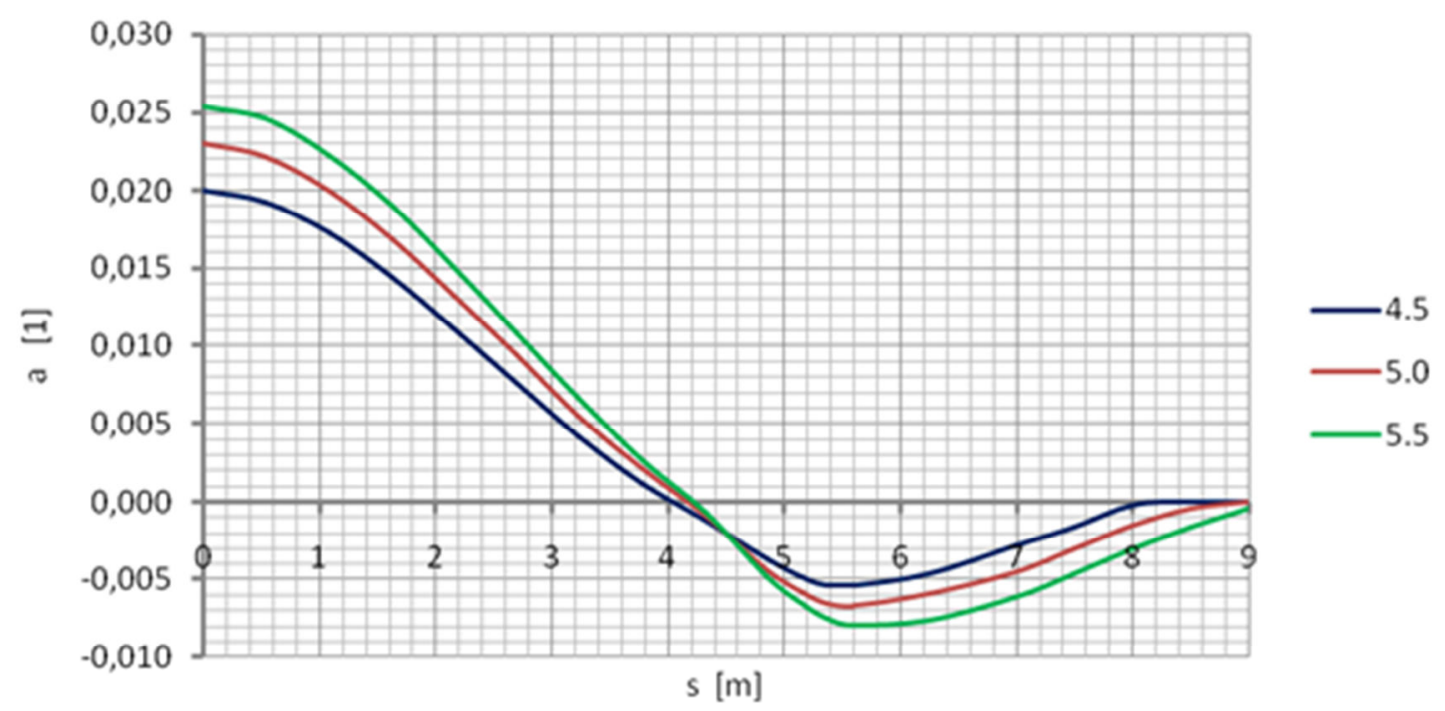

10. Lines of uplift influence as a result of FEM calculations. In the legend, the height of the shell $\mathrm{H}$.

There, three levels of restraint were considered, defined in the height of the shell $H$ as the vertical distance of the key from the place of attachment. On the horizontal axis of the graphs, $\mathrm{s}$ is given as the distance of the analyzed point from the shell key, and in the legend, the value of $H$. Changes in the height of the shell $H$ cause changes in the function of the uplift effect presented in Fig. 10. Obviously, the changes of these ordinates are smooth as it depends on the backfill thickness $z$.

The ordinates of the shell key uplift effect lines as a result of the ground pressure $\mathrm{p}(\mathrm{s})$ were calculated using the FEM program and the shell bar scheme, as in Fig. 7. From these calculations, assuming the vertical force $P=1$ as the resultant soil impact on shell key and using the reciprocity of Betti displacements the effect function $f(\mathrm{~s})$ was obtained. It consists of the dimensionless function $a(\mathrm{~s})$ and the static characteristic of the bent arch stiffness $a \cdot R^{3} / E I$ as in the formula

$$
f(s)=\frac{a(s)}{2} \frac{a \cdot R^{3}}{E I}
$$

The calculations assume symmetry of soil interaction on both sides of the shell, hence the multiplier $1 / 2$ in formula (3). In the case of the analyzed shell in Świdnica, the constant factor is 


$$
\frac{a \cdot R^{3}}{2 E I}=\frac{8,987^{3}}{2 \cdot 5144}=0,7055 \frac{1}{k P a}
$$

As the bending stiffness of the shell, EI/a $=514,4 \mathrm{kNm}^{2} / \mathrm{m}$, a section of a corrugated sheet of the MP $200 \times 55 \times 5,5$ type was adopted with a unit width when $I / a=2,5093 \cdot 10^{-6} \mathrm{~m}^{4} / \mathrm{m}$ and $E$ $=205 \cdot 10^{6} \mathrm{kN} / \mathrm{m}^{2}$. Hence the action of the soil with the radial direction (i.e. perpendicular to the shell) is in the form $p[\mathrm{kPa}]$, and the uplift is obtained from the formula

$$
w(z)=\int_{s_{z}}^{s_{0}} p(s) \cdot f(s) \cdot d s=\frac{a \cdot R^{3}}{2 E I} \int_{s_{z}}^{s_{0}} p(s) \cdot f(s) \cdot d s
$$

depending on the ground level $z$. W (5), the integration starts from the initial point $s_{\mathrm{z}}$, i.e. the contact of the backfill with the coating where $p(\mathrm{~s})=0$. In the case of backfilling, when the backfill is placed over the coating $p(\mathrm{~s})>0$ but $s_{\mathrm{Z}}=0$. The value of so depends on the thickness of the backfill, it is included in the formula (2).

\section{Change in the radius of curvature in a shell key}

The change in the radius of curvature in the shell key, as in Fig. 7, is a characteristic of the shell geometry of the object. In the case of design geometry, there is a relation included in the formula

$$
R=\frac{F^{2}+C^{2}}{2 F}
$$

where the position of point 3 , as shown in Fig. 7, takes the values $F=-z_{3}$ and $C=x_{3}$. After taking into account the displacements $u$ and $w$ this point, as a result of geodetic measurements, there is a change in the radius of curvature in the shell key, determined as in the formula

$$
R_{u w}=\frac{(F+w)^{2}+(C-u)^{2}}{2(F+w)}
$$

In this case, the displacements $u$ and $w$ are referenced to the shell key. Assuming the measurement results from the period when the facility is to be used, in accordance with the data presented in Fig. 11, from the measurement level 7-8, the values of displacements taken in formula (7) are as follows:

$$
w=43+13 / 2=52,5 \mathrm{~mm}
$$

and

$$
u=(20-3) / 2=8,5 \mathrm{~mm}
$$

Hence, the radius of curvature is

$$
R_{u w}=\frac{(1,114+0,0525)^{2}+(4,333-0,0085)^{2}}{2 \cdot 1,1665}=8,599 \mathrm{~m}
$$




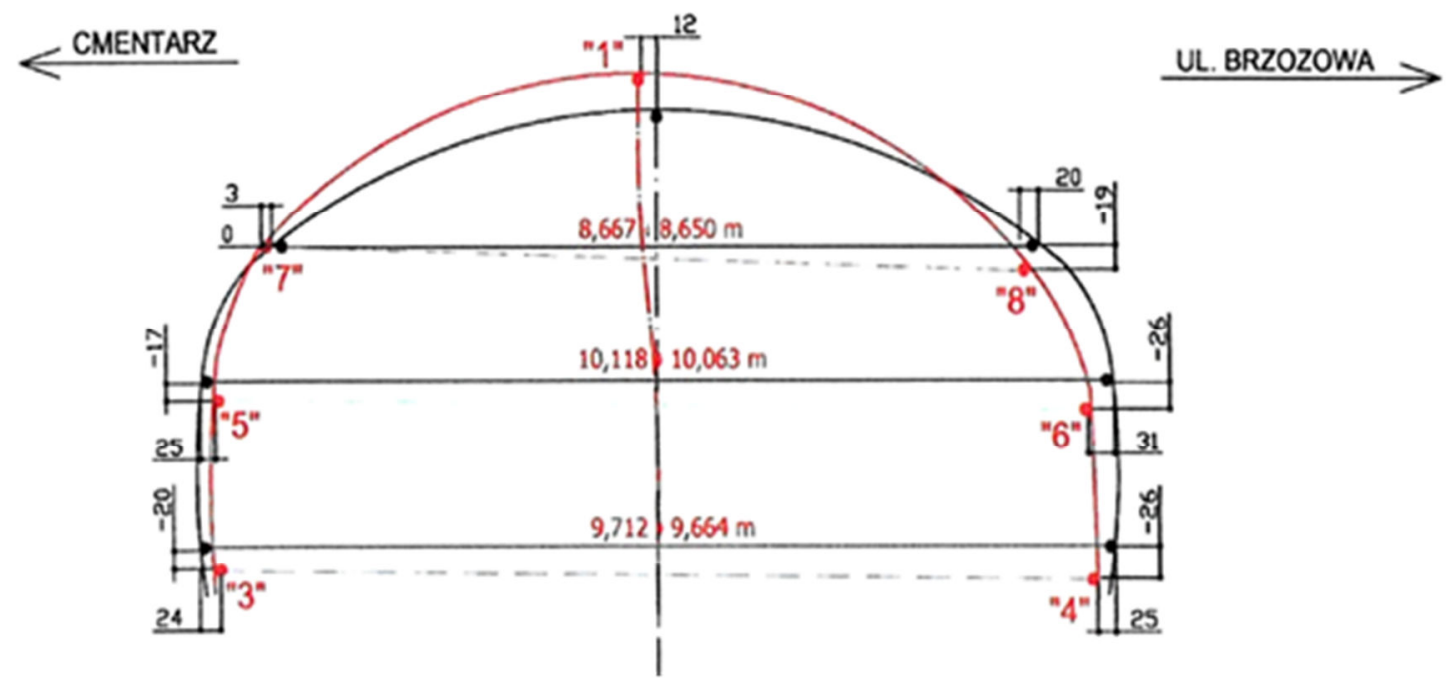

11. Diagram of the deformation of the circumferential strand of the shell after the surface treatment

Thus, the radius of curvature changed by $4.3 \%$. This is a small value compared to those found in classic arc-shaped coatings. In box-shaped shells, the changes in $R_{\mathrm{uw}}(\mathrm{z})$ change differently than in arc-shaped shells [9].

\section{Change of the shell mounting level while the object is in use}

The shell axis displacement diagrams presented in Fig. 9 concern the construction phase. They resulted in a lower and lower level of shell restraint in the column support. Fig. 12 shows the further course of these displacements directed perpendicularly to the circumferential band, i.e. radially.

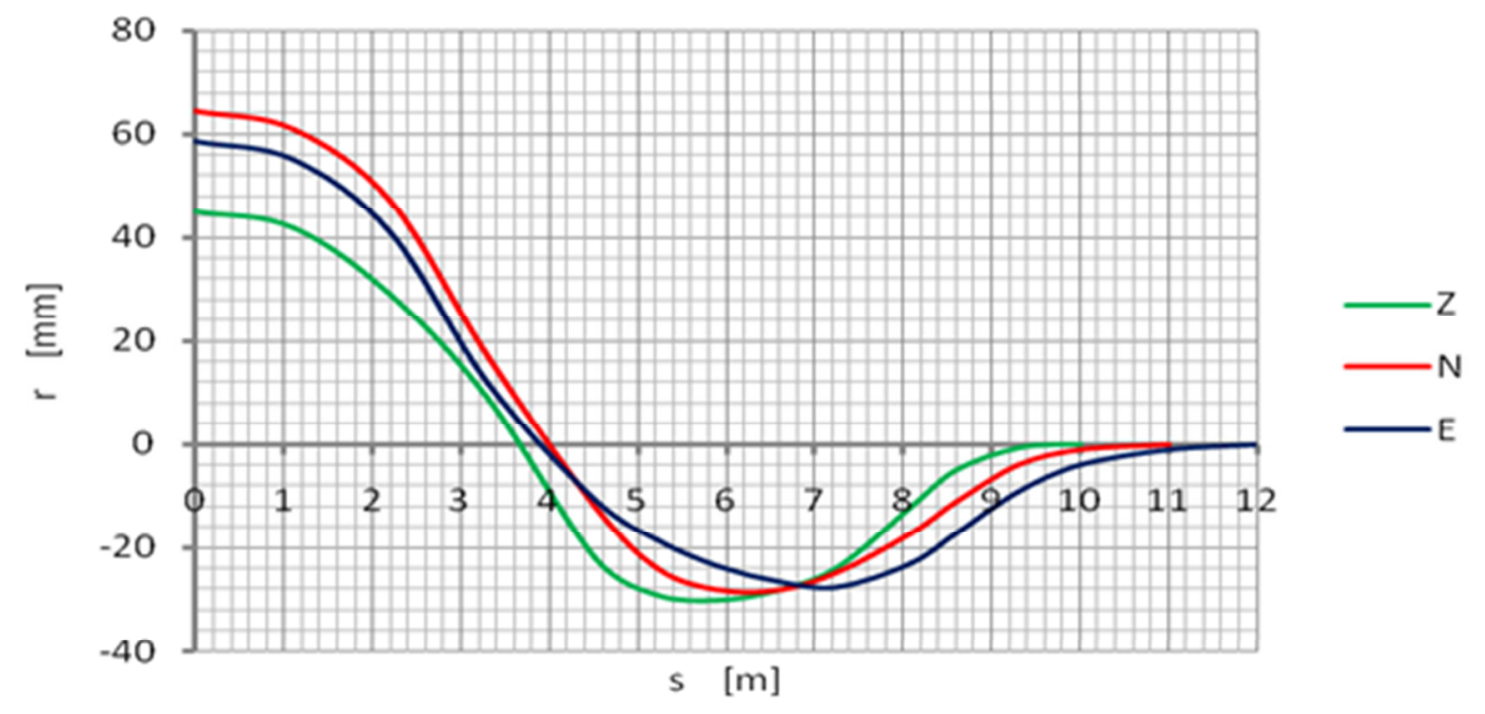

12. Displacement lines of the circumferential strip of the shell depending on the ground level

The situation when the backfill was completed $(z=0,575 \mathrm{~m})$, presented in Fig. 9, was marked as Z. soil pressure on the shell sidewalls over the expansion force from the arched part of the shell. After three years of operation of the object, with a small share of moving loads, there was a reduction in displacements visible in the diagram marked as $\mathbf{E}$. Thus, the effect of the soil on the coating changes, which is observed as a decrease in the level of the coating 
restraint. In this case, it can be estimated (from the extrapolation of the measurement results) at the level of $\mathrm{s}_{\mathrm{o}} \approx 11,5 \mathrm{~m}$ so, when $H \approx 8 \mathrm{~m}$. Only steel pipe piles are present at this level. A decrease in uplift with an increase in the shell height indicates a reduction of soil pressure on the side walls. This phenomenon is observed in soil and coating objects also with the use of pressure Ganges [10].

\section{Summary}

The use of a gutter and massive foundations allows for the fulfillment of the shell support conditions in the form of an articulated and non-sliding scheme. Many research results [9] present examples of the limited freedom of rotation of the shell at the support point. Then, the bending moments at the support point resulting from partial restraint are observed. This effect may be more common with high-wave shells. This is because the support of the shell in the gutter can be realized on the outer or inner crest of the wave and not on its middle part. When the contact zone of the shell with the support is filled with concrete, it leads to the lack of freedom of rotation of the shell in the foundation, and thus a departure from the articulation pattern.

In the case of the shell integrated with the support on piles, it becomes important to determine the static pattern. From the analyzes presented in the work during the construction phase, the place of fixing the corrugated sheet depends on the level of the backfill. In the final stage of construction, the thickness of the backfill is important. In the case of low soil, as in the analyzed example, the pressure of the soil on the side walls prevails. Only at high ground level does the expansion force in the arched part of the shell begins to prevail. During the operation of the facility, the level of shell attachment continues to increase. Thus, when reducing the displacement of the coating, a reduction in the action of the soil is visible.

The flexible support of the steel shell facilitates the formation of a natural vault in the soil backfill and in the native soil medium. In this case, the shape of the shell is important - similar to a parabolic arc. In the case of steel piles, subsidence of the support may be important. In reinforced concrete piles, the side surface resistance is much greater [11].

\section{Source materials}

[1] Machelski C., Michalski J.B.: Podatne posadowienia obiektów gruntowopowłokowych. Obiekty Inżynierskie. nr 1/2009, s. 51-55

[2] Zawieja A, Burek A., Sobala D.: As fast as possible - of a bridge in difficult atmospheric conditions. Archives of Institute of Civil Engineering. 2012, p. 147-156

[3] Graczyk M, Woch M., Skulski B.: Construction of railway bridges made of flexible structural structural plate. Live load test. Archives of Institute of Civil Engineering. 2017, p. 117-124

[4] Wysokowski A, Mońka M., Howis J.: Foundation of flexible structures - developmental trends. Archives of Institute of Civil Engineering. 2017, p. 363-373.

[5] 5. Machelski C., Mońka M.: Prognosis and measurements of deformation of soil-steel structure settled on steel corrugated plate foundations. Archives of Institute of Civil Engineering. 2012, p. 147-156.

[6] 6. Machelski C., Michalski J.B.: Posadowienie mostu gruntowo-powłokowego na ściance z ostrogą. Mosty. nr 3/2008, s. 68-71.

[7] Machelski C., Michalski J.B., Michalski B.: Efektywny most objazdowy gruntowopowłokowy. Inżynieria i Budownictwo. nr 1/2006, s. 11-13.

[8] Michalski J.B.: Posadowienie na rurach stalowych wiaduktu gruntowo-powłokowego w Świdnicy. Obiekty Inżynierskie. nr 3/2009, s. 18-27.

[9] Machelski C.: Badanie mostowych konstrukcji gruntowo-powłokowych. Dolnośląskie Wydawnictwo Edukacyjne, Wrocław 2020. 
[10] Vaslestad J., Kunecki B., Johansen T.H.: Twenty one years pressure measurements on buried flexible steel structure. Archives of Institute of Civil Engineering. 2007, p. 233244.

[11] Gwizdała K., Kowalski J. R.: Prefabrykowane pale wbijane. Wyd. Politechniki Gdańskiej, 2005. 